\title{
QUEEN'S
UNIVERSITY
BELFAST
}

\section{The Year's Work in Stylistics 2016}

Lugea, J. (2017). The Year's Work in Stylistics 2016. Language and Literature, 26(4), 340-360.

https://doi.org/10.1177/0963947017732199

\section{Published in:}

Language and Literature

Document Version:

Peer reviewed version

Queen's University Belfast - Research Portal:

Link to publication record in Queen's University Belfast Research Portal

Publisher rights

(c) 2017 The Author

This work is made available online in accordance with the publisher's policies. Please refer to any applicable terms of use of the publisher.

\section{General rights}

Copyright for the publications made accessible via the Queen's University Belfast Research Portal is retained by the author(s) and / or other copyright owners and it is a condition of accessing these publications that users recognise and abide by the legal requirements associated with these rights.

Take down policy

The Research Portal is Queen's institutional repository that provides access to Queen's research output. Every effort has been made to ensure that content in the Research Portal does not infringe any person's rights, or applicable UK laws. If you discover content in the Research Portal that you believe breaches copyright or violates any law, please contact openaccess@qub.ac.uk. 


\section{The Year's Work in Stylistics 2016}

'We lived in the blank white spaces at the edges of print. It gave us more freedom. We lived in the gaps between the stories.' Margaret Atwood, The Handmaid's Tale (1986/2016: 89)

\section{Foundations for change}

2016 was imbued with a sense of shifting sands in global politics, characterised by very little security in the old or - perhaps more accurately - a sense that tradition can take surprising new forms. In a way, browsing through the titles published in stylistics in 2016 gives the same sense, albeit with altogether more positive developments. I will try to explain what I mean, first looking at the solid foundations on which these changes are wrought. With the recent publication of two discipline-defining handbooks (Burke 2014; Stockwell and Whiteley 2014) and a comprehensive compendium (Sotirova 2015) the contemporary field of stylistics has been very clearly set out. There is general agreement in the remit of research in stylistics, as well as in the eclecticism that it embodies. Sorlin's cross-referencing review of these three volumes, published in Language and Literature last year (Issue 3), makes this harmonious agreement clear, leading her to conclude that stylistics has matured and is indeed in 'good shape'. Reflecting on an outdated suggestion that stylistics lacks an 'autonomous domain of its own' (Widdowson 1975: 3) and that it is a method of analysis rather than a discipline, Sorlin asserts that in the intervening decades stylisticians have succeeded in creating a domain of their own, as evidenced by the publication of these comprehensive volumes.

It is against that background of disciplinary health and energy that I undertake to review subsequent publications in the field, which both contribute to and develop the lay of the land. However, I would venture to surmise that as a result of the sense of confidence in 'our domain', stylisticians are engaging more fully in the interdisciplinary work that has always been at the core of this eclectic field. In the opening lines of her monograph which straddles several sub-disciplines (see Section 5) Sorlin remarks on the ability of stylistics to 'hyphenate' with other areas of language study and the resulting the 'aggregating capacity of the field' (2016: vii). Although referring to discourse analysis more generally, the editors of Exploring Discourse Strategies in Social and Cognitive Interaction (Romano and Porto 2016), introduce their volume by charting merging interests in discourse, society, and cognition which are coming to the fore in language studies that are also cross-linguistic and multimodal. In my view, these interdisciplinary threads are also evident in recent research in stylistics summarised here. Furthermore, not only are stylisticians engaging more fully with other disciplines, but also the long-standing foci of stylistics (e.g. text, cognition, foregrounding, narrative) continue to be issues of interest to scholars in other fields with which we have ongoing fruitful exchanges.

You will notice that the headings I use reflect some of these long-standing concerns of stylistics which have continued into this year (literary stylistics, narrative, corpus stylistics) as well as some more recent approaches that are presently flourishing (worlds-based and empirical approaches). If a sub-discipline of stylistics does not have a heading, it may indeed be subsumed under another heading. Please forgive the categorisations which are not a pigeon-holing exercise, but serve for purposes of readability, a unique challenge for a review article such as this. As always, in order to avoid the problem of self-citation, articles published in this journal are not fully referenced, but I do direct readers to the relevant issue. As I undertake this gargantuan 
task, like the Reviews Editors before me, I am reminded of and also overwhelmed by the scope and variety of research in stylistics. I hope the narrative that follows impresses upon you, as it has done me, the health of our domain which provides us with the necessary confidence to explore beyond it.

\section{Historical Literary Stylistics}

Literature has an enduring fascination for stylisticians, as literary language is where language's most creative users bend and flex linguistic norms for aesthetic and meaningful effects. Many titles outlined under other headings in this review article address literary language, although they do so in specific ways; for example, by considering narrativity, fictional worlds or literary reading practices. The work in literary stylistics summarised here has a historical dimension, focusing, for example, on the stylistics of literature from a certain period, which can either tell us more about the culture of that period, or inform our understanding of contemporary culture, language and descriptive tools. Two key monographs published in 2016 explore a textual phenomenon against the backdrop of the period, from Old English (Louviot 2016) to the Romantic period (Bray 2016a). Both these researchers work towards meeting the objectives of 'historical stylistics' as set out by Auer et al (2016: 1), who propose that in order to uncover how a historical literary text might have been processed by contemporaneous readers, we need to investigate its literary, cultural and linguistic contexts of production and reception. Their edited volume Linguistics and Literary History: In Honour of Sylvia Adamson (Auer et al 2016) celebrates the pioneering research in this field by Sylvia Adamson, whose body of work has brought a diachronic dimension to the study of language and literature. The volume features an impressive catalogue of contributors: Short (2016) analyses a Yeats poem using traditional and cognitive stylistic models, Bray (2016b discusses the French Revolution's influence on first-person representations of consciousness, and two contributions explore the function of parentheticals in the work of Shakespeare (Chen and Duan 2016) and Jane Austen (González-Díaz 2016). Just as stylistics is not limited to literary texts neither is historical stylistics, as evidenced in Evans' (2016) chapter which provides a stylistic analysis of the early letters of Queen Elizabeth I, accounting for her emergent rhetorical powers (for those interested in more heretical Elizabethan texts, see Chaemsaithong's analysis of prefaces to witchcraft pamphlets in Issue 4 of Language and Literature 2016). While all of the contributions to Auer et al's (2016) volume offer comprehensive qualitative analyses of the texts and their historical contexts, they also engage variously with the cognitive and corpus approaches popular in the field at large, lending this volume a broad appeal.

As the 'cognitive turn' shows no sign of abating, stylisticians working in this area may be inspired by Cognitive Approaches to Early Modern Spanish Literature (Jaén and Simon 2016). In this volume, the fields of literary criticism and the cognitive sciences combine, generally bypassing the middle ground that cognitive stylistics occupies. The result is that most chapters overlook the linguistic features of the texts in question, but the volume has significant merit for stylisticians nonetheless. Simon's (2016) introduction contextualises the various cognitive approaches to Golden Age Spanish literature, where literary culture was very much alive and publicly enacted. The chapters that follow consider these rich literary texts and performative contexts using familiar concepts, such as Theory of Mind (Schmitz 2016), embodiment (Mancing 2016; Reed 2016; Cruz Petersen 2016) and empathy (Reed 2016; Simerka 2016). 
The editors describe the volume's research as employing a 'contemporaneouscontemporary methodology' (Jaén and Simon 2016,5), which in its application of cognitive theories from now and then, aims to uncover the relationship between the mind and the arts of the period. In this way, their efforts tally with the aims of historical stylistics as outlined by Auer et al (2016), albeit with a more cognitive and less textual focus. The editors have compiled a volume that appeals to Early Modern scholars beyond Spanish studies and has particular relevance to stylisticians interested in the cognitive processes behind reading, performance, and spectatorship.

Although stylisticians are increasingly interested in the visual and verbal modes, visual art in literary writing, or ekphrasis, is a classic concept in the study of rhetoric. Bray's (2016a) monograph is an account of the intersection of two art forms, fiction and portraiture, during the Romantic period. Bray claims that while critics have remarked on parallel developments undergone by these art forms during the Romantic period, no previous study has investigated the relationship between the two. Beginning by exploring the relationship between the portrait and the novel in general, he then goes on to examine miniature portraits and the Gothic genre, visual and verbal caricature, the idea of 'likeness' in Jane Austen's work, and the Gothic portrait in Sir Walter Scott's fiction. The result is a sensitive and erudite appraisal of the interplay between the two modes, with illuminating insights into subjectivity, the fictional characters and their relationships. Ekphrasis is also the subject of Panagioutidou's article in Language and Literature (2016, Issue 2), where she carries out a cognitive stylistic analysis of the experience of reading a more contemporary literary work: a WD Snodgrass poem depicting a Matisse painting. In describing the correlation between form and effect, Panagioutidou is explicit about her dual role as analyst and reader, a position we could perhaps recognise and problematise more often in stylistics. As we increasingly discuss the cognitive processes involved in literary reading, it stands to reason that we should be more precise about the identity and experience of 'the reader' (and indeed, the reader response research summarised in Section 6 addresses this issue directly).

Louviot (2016) analyses the proliferation of Direct Speech in Beowulf and Other Old English Narrative Poems, the characteristics of which pose interesting challenges to our understandings of viewpoint, characterisation and irony which - as she points out - are largely based on (post)modern literary practices and analyses. Her research demonstrates that including older texts in our analyses can test and challenge contemporary language categories and models. Several articles published in Language and Literature in 2016 took a historical approach to poetry (Vande Wiele, Issue 1 and Weiskott, Issue 4). Beowulf and Middle English verse were used by Weiskott as case studies to explore asystematic metrical patterns. Vande Wiele's article tracks the diachronic loss of poetic effect, charting the move of several French literary expressions from creation to cliché. Her hypothesis that poetic effects diminish over time draws on Relevance Theory (Pilkington 2000; Sperber and Wilson 1995 [1989]) and she consults an impressive array of source material to inform her study, including literary criticism, newspaper corpora, Google Ngram graphs and dictionary entries, which no doubt contributed to this article being awarded the PALA prize. 
Literary narrative has provided stylisticians with infinite analytical possibilities and we continue to investigate its structure (e.g. Klauk et al 2016), as well as the multiplicity of perspectives and voices it evokes and the resultant readerly experience. However, narrative is also a fundamental discourse type which transcends literary and nonliterary uses, as well as spoken, written and (audio)visual modes, and world cultures and languages. Many disciplines operating beyond the boundaries of language and literature have been influenced by a 'narrative turn' in the last few decades, and some scholars (e.g. Beach et al 2016; Beach 2010) would go so far as to propose that narrative thinking underscores most of our thought processes. Although the pervasiveness of narrative thought is debatable, other research points to the potential of narrative to impact on the real world. Naweed (2016), for instance, demonstrates how packaging an unpopular message in a playful Sherlock Holmes style narrative has brought about social acceptance and policy changes in Australia's locomotive industry.

One of several recent titles published in De Gruyter's series 'Narratologia: Contributions to Narrative Theory' pushes the boundaries of narratology as the series editors promise; in Facing Loss and Death: Narrative and Eventfulness in Lyric Poetry (Hühn 2016) the contributors dedicate individual chapters to one or two lyric poems at a time, exploring a great range. The chapters are grouped into sections, sensitively introduced and summarised by the editor: 'Mourning the Death of a Beloved Person', 'Coping with Loss in Love', 'Confronting One's Own Death', 'Lamenting the Death of Poets' and even 'Thematizing the Loss of an Old Order'. Hühn proposes that the lyric poem can be considered a narrative, a view echoed by Eva Zettelmann in her plenary lecture at the International Association of Literary Semantics conference (Zettelmann 2017). As the lyric poems collected in this volume deal with the mental processing of a traumatic event, the strategies the poets use 'usually take a narrative form with the intention of achieving some kind of positive event overcoming and superseding the disruptive effects of the initial negative event (Hühn 2016: 321). Thus, the theme of the poems analysed in this volume is a defining factor in forging what is traditionally recognised as the basis of narrative structure, a sequence of events. Bringing us full circle, an article by Klauk et al (2016) advances a theory of narrative closure that describes how narratives comes to an end, and whether that ending is ascribed by plot, narrator or reader.

If a narrative is most simply defined as a sequence of events, then it stands to reason that texts that use visual means to order events are also ripe for narratological analyses. Developments in our understanding of visual narratives are clearly elucidated in The Visual Narrative Reader (Cohn 2016). With an introductory chapter on 'Interdisciplinary approaches to visual narrative' from Cohn and contributions from other leading scholars on the subject, this book is a vast and instructive account of visual narrative, with three main parts, 'Theoretical Approaches to Sequential Images', 'Psychology and Development of Visual Narrative' and 'Visual Narratives across Cultures'. Every chapter is clearly organised, and those in the first part of the book are most relevant to stylisticians in general, and multimodal researchers specifically; the contributions cover topics such as visual style, coherence, metaphor and cognition. Throughout the Reader, rare objects of study such as Aboriginal sand-drawings and Mayan pottery provide data alongside more typical texts such as cartoons and manga (for the latter genre, see also Cohn and Ely 2016). A detailed exploration of a particular kind of comic book is provided in the monograph Reading Graphic Novels: Genre and 
Narration (Hescher 2016). The author's thesis is that '[u]nlike verbal narrative fiction, graphic novels have no mediating or transmitting communication system, reified in a 'fictional narrator', that could be held responsible for the production of the whole verbal and pictorial discourse. Therefore, the pictorial track should be ascribed to the artistwriter in the external communication system' (2016: 197). The author demonstrates this through the application of Genette's (1980) concept of focalisation, which ultimately proves unsuitable because it does not account for the relation between what an image shows and what characters see, which is essential in the graphic novel's meaning production. Hescher's monograph is a detailed exploration of the genre's characteristic features as well as its narrative mechanisms.

Hescher's contention that the multimodal narrative of graphic novels often lacks a single focaliser might be reconsidered in the light of the argument put forward in Viewpoint and the Fabric of Meaning (Dancygier et al 2016), where the editors and several contributors propose that mixed viewpoints are ubiquitous across languages and text-types (e.g. Dancygier and Vandelanotte 2016). Taking a cognitive linguistic approach, this volume demonstrates that viewpoint continues to be a central concern of narratology but also that, while narratives are still fertile ground for studies of viewpoint, the phenomenon can be better interrogated and developed by looking at non-narrative texts which will challenge traditional viewpoint categories. Incidentally, Cui's (2016) article in Style considers the alternating viewpoints in Virgina Woolf's prose as analogous to adjacency pairs in conversation, which helps to account for the 'social interactive quality' of character consciousness in her literary work. In Perspectives on Narrativity and Narrative Perspectivization, Igl and Zeman (2016) problemetize what exactly constitutes 'narrative', and their eclectic volume recognises that, dependent on the scholarly background and approach, the definition is subject to change. Furthermore, echoing Dancygier and Vandelanotte (2016) who propose that viewpoint is a 'network', they suggest narrativity is a 'perspectival constellation' and the volume's contributions explore this through the analysis of a great range of literary and everyday stories. With recourse to contemporary research into a wide range of differing text types and languages, these two volumes ((Dancygier et al 2016; Igl and Zeman 2016) develop Genette's (1980) two-part distinction between 'who perceives' and 'who sees', pointing to the emergence of a more multi-faceted understanding of narrative viewpoint. Genette's narrative theories are further problemetized by Steinby (2016), who questions whether their basis on physical terms is appropriate for the study of literature and subjective human experience.

Our understanding of 'who perceives' in narrative is greatly influenced by the textual expression of 'voices', another classic concept in narratology that is expanded in recent research, with Scott's analysis of working-class idiolects in Sillitoe's prose fiction (Issue 4 of Language and Literature) and Foxwell's (2016) consideration of how the narrator's voice intrudes on the fictional world of The Comforters to produce hallucinatory effects. Foxwell draws on the field of audionarratology, which was greatly advanced in 2016 through the publication of a dedicated volume in the Narratologia series (Mildorf and Kinzel 2016). The editors of Audionarratology: Interfaces of Sound and Narrative point out that sound has indeed been implicit in earlier narrative scholarship dealing with, for instance, the aforementioned concept of 'voice' in fiction, or texts such as spoken narrative, radio plays and audio guides. The contributions to their volume explore digital stories, video games, experimental theatre and art, as well as country and blues music (see also Barlow [2016] on narrative in the blues). The 
editors claim that '[a]udionarratology analyses how sounds and noises contribute to the creation of real and imagined spaces and words' (Mildorf and Kinzel 2016: 19) but recognise that, as a nascent field, where even the definition of 'sound' is ill-defined (for example, is it situated with the hearer or producer?), there remains much work to be done. This volume is an exciting statement from an expanding field.

Any consideration of sound and narrative is naturally appreciative of the experience of processing narrative, and this experientiality is also the subject of more recent narratology at large. For instance, in Making Sense of Narrative Text Toolan emphasises 'the central roles of situation, repetition and picturing in the reader's making sense of a literary story, and the reader's emotional engagement both drives and draws on these three considerations' (2016: 39). In order to empirically test his concept of High Emotional Involvement, Toolan uses questionnaires to gather reader responses to a short story, a method that will interest the growing number of stylisticians interested in empirical and reader response methods (see Section 6 of this article for a detailed review of such research). Considering the various contexts in which narrative is produced and received is advantageous in developing narratological concepts, as an article by Lively (2016) demonstrates. He shows that traditional semiotic dyads such as sender/receiver fall flat when considering young children's narrative use, and that the concept of 'joint attention' from developmental psychology can better account for literary narrative, with its 'nested perspectival prisms of embedded narrative and character' (2016: 517).

No sooner than readers (real and professional) became accustomed to the conventions of literary narrative, writers began to play with those conventions, producing what Richardson (2015) has termed 'unnatural narratives', those that loudly call attention to their fictionality and artifice. In a Special Issue of Style dedicated to the subject (Richardson 2016a), the guest editor defines unnatural narratives as not just non-mimetic, defying realism, but rather as playing 'with the very conventions of mimesis' (Richardson 2016b, 386) and consequently 'antimimetic' (Richardson 2016b, 389). The responses to Richardson's introductory article probe the scope and definition of the concept further, with provocative contributions from Shen (2016) and Ryan (2016) amongst others. Continuing her innovative research on digital fiction, an ideal medium for testing the boundaries of narratology, Bell's (2016) article in Narrative questions whether digital fiction can be called 'unnatural narrative' when metalepsis, the blurred boundary between fictional and real worlds, is in-built to the way in which this type of literature is processed. Thus, the definition of what is 'unnatural' in narrative depends on what is 'natural' in a given narrative context.

\section{Worlds}

Although they may appear under other headings in this article, many recent studies in language and literature refer to 'worlds' (e.g. Short 2016; Toolan 2016; Tabbert 2016; Mildorf and Kinzel 2016; Sorlin 2016; Zyngier 2016; Zettelmann 2017). The term has become ubiquitous metaphorical shorthand for describing, in general, the reality projected by a text. Given the preponderance of the term in recent scholarship, it 
merits an inaugural heading in 'The Year's Work in Stylistics'. However, the definition used across scholarship in language and literature is variously well or ill-defined and differs according to the research approach adopted. I outline three general ways in which the term is used, before summarising 2016's research into worlds in language and literature.

In outlining the specific aims of critical stylistics, Jeffries (2015: 160) states that 'the critical-stylistic approach to exposing ideology is to find out what kind of world is being presented by the text'. This typifies the first way in which the term 'world' is used to refer to the representational aspects of a text, common in critical linguistics more generally and sometimes employed in literary studies. Critical linguistics is founded on the idea that texts encode particular representations of the world, and, conversely, that texts play a critical part in constructing social 'realities'. Thus, critical linguists use the term 'world' to reflect two sides of the same coin; a) how the world is represented in a text and b) the reality it subsequently produces (see, for example, Davies 2013; Tabbert 2015; Tabbert 2016; Jeffries 2015). Prefacing her recent investigation into readers' movements between fictional and real worlds, Bruns refers to the opinion of some literary scholars that works of literature are 'repositories of worldviews' (2016: 351), which also emphasizes the representational role of literature. In their early account of mind style in fiction, Leech and Short distinguish between the fictional world as 'what is apprehended' and worldview as 'how that world is apprehended, or conceptualized' (1981: 187). This demonstrates that stylistics has long made a distinction between the world of a text and the worldview(s) imbued therein, yet some scholarly uses of 'world' pertain more to the 'how' than the 'what'. It is important to distinguish this first sense of the term 'world' which refers to a text's representational function - ideological or aesthetic - from the second and third senses in which a 'world' is an ontological textual construction.

The second use of 'world' is specific to the alternative reality engendered by a fictional text (a fictional 'what', if you like). Based on the ideas advanced by possible worlds theorists (e.g. Kripke 1972; Rescher 1975; Lewis 1986) who discussed the human capacity to conceive of alternative realities, literary semioticians have explored the ways in which fictional worlds differ from the real world in patterned ways (e.g. Ryan 1991). Such approaches are particularly useful for considering the ontological status of fiction and the characteristics that constitute literary genres, both considered in terms of their 'accessibility' to features of the real world. In a recent monograph which chimes with the work of possible worlds scholars, Pettersson (2016) takes a comparative literature approach to the concept of the 'literary world', which he defines as 'the imagined scenario of a literary work as shaped by thematic and formal means' (2016: 6). His central argument is that the human imagination is prone to creating fictional spaces, which can be delivered in three modes (oral, visual and written) and which tend to deal with one of three themes (challenge, perception and relation). Pettersson makes his case with recourse examples from an impressively vast range of literary genres, eras and cultures. While Petersson's approach may lack an observance of textual features for some stylisticians, there are forays into familiar fodder, such as metaphor and narratorial unreliability, which will no doubt be of interest. With literary history and cultural theory as reference points, Pettersson highlights how literary worlds shape and influence the real world which corresponds 
with the critical linguistic understanding of the impactful role of 'worlds' in discourse outlined above.

While the term 'world' provides a convenient metaphor in literary scholarship, there is a lack of criteria as to how a 'world' is constructed in discourse and a focus on fiction, to the neglect of other discourse types (a recent exception is Candel Bormann's [2016] application of possible worlds theory to literary history texts, rather than literature itself). These issues are addressed by the third definition of 'world', as set out in Text World Theory, advanced first by Werth (1999) and developed by Gavins (2007) and such a growing number of researchers that it needs little introduction here. Text World Theory builds on the idea that a text creates a distinct ontological space, and drawing on insights from the cognitive sciences, it refers to the impression of a text generated by participants during any kind of discourse. A 'text-world' is activated by textual features and supplemented by discourse-world features, such as participants' relevant experience and knowledge stores. In a chapter dedicated to the model in The Bloomsbury Companion to Stylistics, Gavins declares Text World Theory is 'now one of the most dynamic areas of research in contemporary stylistics' (2015: 444). This is no doubt in part due to the way in which it allows the analyst to consider overall discourse structure, as well as text and context under one framework. The term 'textworld' has now fully entered the stylistic lexicon, being the focus of two books published in Bloomsbury's 'Advances in Stylistics' series in 2016.

First, the edited volume World Building: Discourse in the Mind (Gavins and Lahey 2016) brings together exciting new research into world-building in a great variety of discourse types. In their introduction, the editors describe the emergence and development of worlds-based research in all its guises and in more detail than possible here. The contributions go beyond the worlds-based analysis of literary texts typical of earlier research in the field. Readers are granted insights into discourse processing in the school literature classroom (Giovanelli 2016), in creative writing practice (Scott 2016) and in the negotiation of identity in an ethnographic interview (van Der Baum 2016). As these examples also show, the focus of the volume is more on the process of world-building; that is, the dynamic and collaborative nature of production and reception of texts. For although cognitive poetics resolves to take context seriously (Stockwell 2002: 4), in practice contextual factors have been largely sidelined in the pursuit of understanding textual features in terms of relevant abstracted cognitive processes. Until recently, Text World Theory was no different: it implicitly recognised the discourse-world as an integral part in world-building, but the influence of discourseworld features on the text-world remained relatively unexplored (see Gavins 2015 for further discussion and development of this interface). Several chapters in Gavins and Lahey's volume advance Text World Theory's capacity to deal with the discourseworld; Lahey (2016), for example, demonstrates the influence of the text-world on our understanding of the discourse-world from which it emerges and Gibbons (2016) explores the interaction between fact and fiction in immersive theatre. In other contributions worlds-based approaches are proven to work comfortably alongside other frameworks, such as Stockwell's (2009) model of literary resonance (Whiteley 2016; McLaughlin 2016) and Conceptual Metaphor Theory (Browse 2016 and in Issue 1 of Language and Literature). This volume is testament to the varied research that Text World Theory has inspired and, with its focus on world-building, how it is working towards marrying the 'what' and the 'how' of text-world construction. 
The second title dedicated to text-worlds in Bloomsbury's 'Advances in Stylistics' series last year adapts Text World Theory for the analysis of Spanish discourse, further widening the model's scope. In World Building in Spanish and English Spoken Narratives (Lugea 2016a) Text World Theory is tested and developed by analysing many oral versions of the same story, transcribed to create a corpus of spoken narratives. The data is gathered using the 'frog story method' (Berman and Slobin 1994), whereby a wordless picture book is used to elicit spoken narratives from participants. The Spanish and English narratives are analysed qualitatively and quantitatively to contrast world-building strategies in the two languages, with particular attention to modality, hypotheticality and deixis (see Lugea 2016b and Baroni 2016 for a specific focus on temporality in spoken narratives). Lugea's (2016a) monograph offers unique insights into rhetorical differences in Spanish and English storytelling styles and the ways in which these speakers implicate themselves in text-worlds. The use of software to create text-world diagrams (first employed in Lugea 2016a) has been advanced by stylisticians working with computer scientists to develop an online software, Worldbuilder 1.0. The first version of Worldbuilder comprises of an online data annotation and visualisation tool for text-world analysis, described more fully in Wang et al. (2016). With their focus on the linguistic features used in text-world creation, Lugea (2016a; 2016b) and Wang et al. (2016) are more concerned with the formal, textual operations in 'world-building' than the discursive research in Gavins and Lahey (2016). Nonetheless, with so many elements involved in discourse processing, it stands to reason that Text World Theory has inspired research into multiple aspects of world-building.

\section{$\underline{4 \text { Critical Stylistics and Discourse Analysis }}$}

As the summary of worlds-based research has shown, stylistics is interested in both what and how experience is captured in discourse. While literary texts - historically and currently - may be the mainstay of stylistic enquiry, any text where patterned choices add up to some sort of discernible 'style' are worthy candidates for investigation. Arguably, with its emphasis on foregrounding, cumulatively patterned choices and potential effects, stylistics is well-suited to exposing textual practices in ideologically-motivated texts. News discourse has long been the obvious place to look for the expression of dominant ideologies, as political and social events are selected, linguistically constructed, and published as irrefutable 'fact'. Recent research continues to shed light on the link between journalists' linguistic choices and their conceptual construals, whether through transitivity (e.g. Lee 2016) or metaphor (e.g. Browse 2016). My opening observation that tradition can take surprising new forms, in discourse and discourse analysis, is clearly demonstrated in a fascinating article by Bednarek (2016). She creates a corpus of the most shared English-language news articles on Facebook and analyses their news values and evaluation quantitatively and qualitatively. Her findings show that traditional news values are upheld in the modern context, but also that 'unexpected', 'affective' and 'negative' news may be worthier of sharing on social media. Research such as this demonstrates the importance of doing discourse analysis as the sands on which discourse is shared shift. News-speak is no longer the language of an institutional elite, but operates on a more interactive and no 
less slippery digital platform, where 'fake news' abounds. However, crying 'fake news' entails the assumption that the opposite concept 'real news' is a given and critical linguists have long been disproving that assumption by revealing the representational nature of language (see Section 3).

While the reliability of news discourse has only recently come under public scrutiny, folk linguistic notions about women's language continue to pervade popular opinion and evaluations of women in power. Cameron and Shaw's Gender, Power and Political Speech: Women and Language in the 2015 UK General Election (2016) works towards revealing the true characteristics of female politicians' speech, in light of highly gendered reporting in the British media. The quick turnaround promised by Palgrave's Pivot series allows for a timely publication of the topical case study, which the authors use to demonstrate how the widely-held 'difference' account of women's language is refuted by their findings on the politicians' true debating styles. Another title in Palgrave's pithy Pivot series is Ringrow's (2016) The Language of Cosmetics Advertising. The beauty of this research is in the creation and analysis of a crosslinguistic corpus of adverts, gathered from magazines in Anglophone and Francophone cultures. Ringrow's analysis draws on a range of relevant frameworks from Chapters 3 to 5, beginning with her adapted version of the Problem-Solution model (Hoey 1983), which also informed Jeffries' (2007) critical stylistic investigation into representations of the female body. Chapter 4 deals with the advertisements' binding of femininity with sensuality, including a consideration of multimodal elements (see also Hidalgo Downing et al.'s [2016] analysis of multimodal metaphor in TV cosmetic adverts). Chapter 5 explores the 'scientised' discourse of beauty adverts as a means to assert the advertisers' authority. Finally, Ringrow reflects on the implications of her findings for the Feminist Critical Discourse Analysis approach (FCDA [Lazar 2005; 2007]); yet, with Ringrow's dedication to textual features, her work sits comfortably within the remit of critical stylistics (Jeffries 2007; 2009).

Members of PALA's Crime Special Interest Group are well-served by the publication of several quality monographs on the topic of language and crime in 2016. Following her detailed analysis of representations of crime in the British and German press (2015), Tabbert's second monograph (2016) serves as a less investigative and more instructive publication, with the focus on explaining how critical and corpus stylistic methods can be used in this kind of study. Her research is inspired by her professional experience as a prosecutor in the German justice system and by the discrepancy she has observed between criminals in reality and in their media representations. Like Statham (2016), she is critical of the role of the media in judicial proceedings and both scholars advance powerful critical discourse analyses of the influence of ideology on criminal court proceedings and their media representations, which will no doubt fascinate researchers of CDA and critical stylistics, as well as forensic linguists. Both Statham (2016) and Tabbert (2016) use corpora to support the qualitative analyses of their data; while Tabbert's work sits firmly within the remit of critical stylistics, Statham deftly navigates the critical-forensic interface of linguistics. In both books, the clear organisation and logical progression of the arguments make them a pleasure to read.

Linguistic manifestations of power and ideology are also under investigation in Sorlin's (2016) Language and Manipulation in House of Cards: A Pragma-Stylistic Perspective, although her data is the fictional drama series, recently recreated and aired by Netflix. Sorlin discusses Wodak's (2011) notion of the 'fictionalisation of 
politics' whereby the political sphere is increasingly the subject of fictional representations (see also The West Wing, Borgen). As Sorlin suggests, nowhere is the boundary between fact and fiction so formally foregrounded than in House of Cards, where the protagonist frequently breaks the fourth wall to address the viewer directly. Sorlin analyses these asides, as well as other features of the dialogue and visual elements using an impressive array of frameworks, reflecting the encompassing nature of the 'pragma-stylistic' perspective her book title promises, and more. For example, among the frameworks she draws on to explore manipulation are conceptual metaphor theory (Lakoff and Johnson 1980) visual grammar (Kress and van Leeuwen 2006) and (im)politeness theory (Leech 2014). Based on the character of the ruthless politician, Frank Underwood, Sorlin also proposes an addition to Grice's Cooperative Principle which she terms the 'Manipulative Principle': 'Make your conversational contribution such as is required [...] while hiding your real intentions so as not to be held accountable for what you say' (Sorlin 2016: 109), seemingly bridging the traditional Gricean maxims of Quantity and Quality for manipulative purposes. She develops a set of maxims related to this principle, an example of how throughout the monograph, her applications of models to this groundbreaking TV series leads to insights into both the data and the theoretical frameworks.

\section{Empirical Stylistics}

Stylistic enquiry usually involves the rigorous analysis of textual features and suggestions as to their effects, often without recourse to empirical evidence for the latter. Addressing this methodological imbalance are a growing number of researchers investigating 'real' responses to texts, as evidenced by PALA's Special Interest Group, 'Reader Response Research in Stylistics', as well as Special Issues of Language and Literature dedicated to 'Reading in the Age of the Internet' (Issue 3, 2016) and 'Stylistic Approaches to Reader Response Research' (Issue 2, 2017). Because empirical methods are a way to test pre-determined theories and those theories can be drawn from any number of approaches to text and discourse, the empirical research summarised here intersects with various other sub-disciplines, from ethnography to pedagogical stylistics.

Given that the everyday business of most stylisticians is education, it is no surprise that this setting is explored in their research. Reflecting the interdisciplinary nature of our subject, stylisticians often teach language and literature more broadly, and the stylistic toolkit can be of use outside of the stylistics classroom. Thus, a distinction can be made between teaching stylistics itself, and the use of stylistic techniques in teaching, or 'pedagogical stylistics' (see, for example, McIntyre 2011). The studies in Scientific Approaches to Literature in Learning Environments (Burke et al. 2016) are underscored by an empirical approach to investigating how literature is taught and learned. They explore the use of literature in EFL and L2 classrooms, but also on other programmes in schools and universities, as well as in the workplace and in book groups. The contributors gather evidence using an interesting range of methods, including think-aloud protocols (Vassallo 2016; Janssen and Braaksma 2016), student questionnaires (e.g. Zyngier and Viana 2016) and written reader responses (Sotirova 2016). In the introductory chapter, the editors argue that 'results derived from empirical 
research allow for evidence-based pedagogical decisions' (Burke et al. 2016: 6) and after an overview of relevant research, they reiterate Burke's point that 'while doing stylistics for the sake of ourselves is a pleasurable exercise, doing it for the sake of our students is a commendable necessity' (2016: 11).

Certainly, it makes sense to investigate the learning environment in which many of us operate, and there is no doubt that our daily work supplies us with rich data from which to observe reading practices (a method that goes back to IA Richards and continues today; see, for example, Bruns 2016). However, in order to understand the reading practices of the population outside of academia, reader response research should be undertaken in non-academic settings. The book club or reading group offers such a setting, albeit with quite particular interactional characteristics in offline groups (Llopis et al. 2016) as well as online (Vlieghe et al. 2016). In Talk about Books: A Study of Reading Groups, Peplow (2016) employs an ethnographic method of gathering spoken data from real readers as they discuss fiction together, resulting in transcripts from over twenty-four hours of situated talk. He takes a discourse analytical approach to the data, finding in these 'Communities of Practice' that directly reported speech allows participants to simulate characters' minds and mimetic reading allows them to talk about fiction as if it were real life. While the research carried out by Peplow does not involve stylistic analysis directly, his findings are pertinent to cognitive stylistics where the interaction of readerly minds with texts is much discussed, but little supported with empirical data (see a critique of this tendency in Miall 2006: 39-43).

Some recent research in cognitive narratology employs empirical methods to test the functions of narrative devices. Fletcher and Monterosso (2016) for example, test the claim that Free Indirect Discourse has an empathetic effect on student readers by conducting a reading experiment, using FID-enriched and control texts as stimuli, and they gather responses through follow-up questionnaires. Their findings suggest that the direction of deictic movement - from third to first person or vice versa - results in two different cognitive effects, empathy or 'alterity' (i.e. an othering effect). Keen (2016) praises the research design, but suggests that empathetic experience involves several distinct phenomena (perspective-taking, sympathy and emulation, amongst others), nuances which are overlooked in Fletcher and Monterosso's (2016) research design. Keen also recommends ensuring the subject pool is as broad as possible and suggests using online tools to crowdsource a larger, more diverse pool of paid subjects. On other recent innovations, reader response methods collide with creative writing methods in Clode and Argent's (2016) study, which asks readers to engage in a digital 'choose-your-own-adventure' story. With the participants featuring as both 'author' and reader in the second person narrative, the researchers explore the relationship between the participants' gender and their construction of the story world, with fascinating results. 


\section{Corpus Stylistics}

Although some of the aforementioned publications have been supported with corpus methods (e.g. Lugea 2016a, 2016b; Ringrow 2016), here we examine several publications that employ a more corpus-driven approach. Reflecting the continued interest in corpus stylistics, several journal articles use corpora to glean insights into literary texts. Building on previous corpus research by Mahlberg (2013) on Dickens' characters, Ruano San Segundo uses WordSmith Tools to analyse the speech reporting verbs in a corpus of fourteen Dickens novels, which he finds contribute to the formation of Dickens' remarkable characters (Language and Literature 2016, Issue 2). Last year this journal also published corpus analyses of viewpoint in Lady Chatterley's Lover (Ikeo, Issue 2) and of stylistic differences in an Italian translation of a Julian Barnes novel (Johnson, Issue 1). Taking a diachronic approach, Hule and Kestemont (2016) use corpus methods to identify distinct periods in Samuel Beckett's oeuvre in French and in English.

Nowhere is the emphasis on the power of corpora more emphatic than in Louw and Milojkovic's (2016) co-authored monograph Corpus Stylistics as Contextual Prosodic Theory and Subtext. They advance challenging critiques of contemporary language study in general, and cognitive approaches in particular, contending that '[c]reating an additional class of abstractions and then using them on real data is at its best unnecessary and at its worst misleading' (2016: xv). Instead, they emphasise that 'corpora deliver data with the quantity, empiricism and force of a fire hose that falsifies the concepts brought before it' (2016: xv). Many stylisticians would agree with the importance of developing empirical, data-driven theories of language, but balk at the all-out rejection of alternative paradigms (see Mahlberg et al. [2016] and Busse [2011] for examples of how corpus and cognitive approaches can be complementary and Jeffries [2000] in defence of theoretical eclecticism in stylistic analyses more general). As Strive observes in the introduction to the Bloomsbury Companion, '[m]odern stylistics, even when embracing the more interesting aspects of cognitive theory [...] retains a theoretical and practical focus on the structural and linguistic artfulness of the text' (2015: 12). For Louw and Molojkovic, the text's artfulness is measurable only in relation to observable data, through corpora or empiricism. Part 1 assembles previously unavailable work of Louw's which advances Contextual Prosodic Theory (CPT) and describes semantic prosody and delexicalisation - phenomena first observed by John Sinclair - and relexicalisation and subtext, Louw's own contributions. For example, in Chapter 1 Louw demonstrates through corpus stylistic analyses that over the course of several poems, literal word meanings are delexicalised in favour of less literal meanings and subsequently relexicalised, their literal meanings restored; these interpretations are made with recourse to the words' collocation patterns. The subsequent chapters develop the notion of semantic prosody and collocation in the context of Firth, Halliday and Sinclair's definitions (see Baker's [2016] development of collocation analysis by using graph theory to reveal a more multidirectional understanding of the company words keep in corpora). Collocation and semantic prosody are applied in Louw's later chapters in relation to irony, humour, negotiation and institutional discourse. This is followed in Part 2 by Milojkovic's application of CPT to texts in Russian and Serbian, demonstrating the theory's transferability to other languages. First, Milojkovic uses Alexander Pushkin's poetry to consider CPT's key 
phenomena in the context of the new languages and then, in later chapters, employs some creative and empirical means to advance CPT. For example, she compares a human literary translation with a corpus-generated one, sets creative writers the task of identifying 'inspired' moments in their output, and employs CPT in the stylistics classroom. Whether or not you agree with their dismissal of attempts to describe the conceptual underpinnings of discourse and discourse processing, the authors' dedication to data and the scientific method is laudable.

Louw and Milojkovic recognise that '[t]he advent of corpus stylistics has been a byproduct of the creation by John Sinclair' $(2016,82)$, the great linguist whose work has inspired an edited collection to address the fact that 'not enough is known about his contributions as a stylistician and a specialist of language and literature education' (Zyngier 2016: xiii). Thus, corpora play only a supporting role in a collection that is divided into three parts. Part 1 'Education, language teaching and stylistics' includes four chapters of Sinclair's writings on very practical classroom issues such as language development and awareness, and the value of corpora in teaching. Part 2, 'Linguistic Stylistics', presents five chapters on Sinclair's brilliant textual analyses of predominantly poetry. Always aware of the relationship between an individual instance of language use and the system at large, to Sinclair a poem is 'a sample of language; perhaps not a representative sample, but only carrying meaning because it can be referred to a description of a whole language' (Zyngier 2016: 44). Part 3, 'Style and Discourse' explores literary texts at the level of discourse with, for instance, a chapter on the interactional demands of writing for unseen readers and another on 'Fictional worlds revisited'. Stylisticians working with worlds-based theories will be particularly interested in the latter, Sinclair's re-writing of an earlier publication, not easily available until now. In this chapter, Sinclair suggests that the status of a discourse as fiction or fact is not dependent on its correspondence with anything in the real world, but is agreed or negotiated by speakers. Text-world theorists will notice interesting parallels with Werth's (1999) notion of Common Ground and readers of 'fake news' will know that this is no more questionable than 'real' news. The philosophical insight demonstrated in the chapter is explained in the volume's coda, wherein Bill Louw reveals the little-known fact that Sinclair's MA degree was in philosophy. Zyngier has thoughtfully selected and compiled the works of Sinclair that are most relevant to stylisticians and, as ever, the linguist's brilliance shines through in his attention to the text, his grasp of the wider language system and the practical classroom applications of his insights.

The practice of using corpora in the classroom continues developing along with corpus and pedagogical methods. Mahlberg and Stockwell (2016) provide a strong case for using corpus stylistics as a starting point in teaching literature and, introducing their new online CLiC tool, explore sample exercises to do so. The same tool is outlined in an article in Corpora (Mahlberg et al. 2016), where the authors describe CLiC's use for automatically tagging text that falls within or outside quotation marks. Using Dickens' novels as a case study, the authors demonstrate 'CLiC's capacity for differentiating between speech and non-speech narratorial framing, as well as its identification of suspensions of varying lengths between speech' (Mahlberg et al. 2016: 450). The concordances and clusters are used in conjunction with the cognitive poetic notion of 'mind-modelling' to reveal how the contents of direct speech, as well as the frame within which it occurs, contribute to textual characterisation. This 
research project demonstrates how corpus and cognitive approaches can actually work together, providing hypothesis-led findings about the language of fiction.

\section{Conclusion}

With corpus methods providing tools to improve our understanding of bottom-up features, and empirical methods lending the means to test our observations of topdown processing, stylistics is looking not only 'in good shape', but scientifically strong. Mixed-method research, such as Mahlberg et al.'s (2016), is a reminder that stylistic investigation is at its strongest when (a) supported by evidence (in textual or empirical data) and (b) it implements analytical model(s) which clarify the researcher's understanding of the data and ensures interpretative precision and replicability. After an exhausting but thrilling survey of the year's work in stylistics 2016, I think we can conclude that this methodological eclecticism is at the heart of the discipline's health and rigour. Furthermore, the confidence felt in the discipline's domain is reflected, as I suggested in the beginning, in stylisticians' widening engagement with other fields in the humanities and sciences.

It is with mixed feelings of pride and trepidation that I present on the PALA website the list of titles published in 2016-7 for review in Language and Literature (see page $X$ of this issue); pride, because they seem to outnumber lists published in previous years (whether this is down to an increase in our scholars' fervent activity, our scholastic membership, or my own overly-zealous identification of titles that might interest our membership, I do not know), and trepidation, because I have to summarise them all for you next year. Until then, if not before. 


\section{References}

Atwood M (1985/2016) The Handmaid's Tale. London: Penguin.

Auer A, González-Díaz V, Hodson J and Sotirova, V (eds) (2016) Linguistics and Literary History: In honour of Sylvia Adamson. Amsterdam and Philadelphia: John Benjamins.

Baker, P (2016) The shapes of collocation. International Journal of Corpus Linguistics 21(2): 139-164.

Barad K (2003) Posthumanist performativity: Toward an understanding of how matter comes to matter. Signs: Journal of Women in Culture and Society 28(3): 801-831.

Barlow D (2016) Blues narrative form, African American fiction and the African diaspora. Narrative 24(2): 134-155.

Baroni R (2016) Dramatized analepsis and fadings in verbal narratives. Narrative 24(3): pp. 311-329.

Basu L (2015) TV satire and its targets: Have I Got News for You, The Thick of It and Brass Eye. In: Meijer Drees M and de Leeuw S (eds) The Power of Satire. Amsterdam and Philadelphia: John Benjamins, pp. 207-215.

Beach LR (2010) The Psychology of Narrative Thought: How the Stories We Tell Ourselves Shape our Lives. Bloomington, IN: Xlibris.

Beach LR, Bissell BL and Wise JA (2016) A New Theory of Mind: The Theory of Narrative Thought. Cambridge Scholars Publishing.

Bednarek M (2016) Investigating evaluation and news values in news items that are shared through social media. Corpora 11(2): 227-257.

Bell A (2016) Interactional metalepsis and unnatural narratology. Narrative 24(3): 294310.

Berman R and Slobin D (1994) Relating Events in Narrative: A Crosslinguistic Developmental Study. Hillsdale, N.J.: Lawrence Erlbaum Associates.

Bray J (2016a) The Portrait in Fiction of the Romantic Period. London and New York: Routledge.

Bray J (2016b) The first person in fiction of the 1790s. In: Auer A, González-Díaz V, Hodson J and Sotirova V (eds) Linguistics and Literary History: In honour of Sylvia Adamson. Amsterdam and Philadelphia: John Benjamins, pp. 111-127.

Browse S (2016) This is not the end of the world: situating metaphor in the textworlds of the 2008 British financial crisis. In: Gavins J and Lahey E (eds) World Building: Discourse in the Mind. London and New York: Bloomsbury, pp. 183-201.

Bruns, CV (2016) Reading readers: Living and leaving fictional worlds. Narrative 24(3): 
351-369.

Burke M (2014) (ed) The Routledge Handbook of Stylistics. London and New York: Routledge.

Burke M, Fialho O and Zyngier S (eds) (2016) Scientific Approaches to Literature in Learning Environments. Amsterdam and Philadelphia: John Benjamins.

Busse B (2011) Writing is medicine: Blending cognitive and corpus stylistics. In: Callies M, Keller WR, Lohöfer A (eds) Bi-Directionality in the Cognitive Sciences: Avenues, challenges, and limitations. Amsterdam \& Philadelphia: John Benjamins, pp. 121156.

Cameron D and Shaw S (2016) Gender, Power and Political Speech: Women and Language in the 2015 UK General Election. London: Palgrave Macmillan.

Candel Bormann D (2016) Possible worlds in the history of the novel. Poetics Today 37(1): 107-136.

Cohn N (2016) The Visual Narrative Reader. London and New York: Bloomsbury.

Chen G and Duan S (2016) Decoding the parenthesis in Shakespeare's Coriolanus: A functionalist approach. In: Auer A, González-Díaz V, Hodson J and Sotirova V (eds) Linguistics and Literary History: In honour of Sylvia Adamson. Amsterdam and Philadelphia: John Benjamins, pp. 86-109.

Clode D and Argent S (2016) Choose your own gender: An interdisciplinary approach to studying reader assumptions in second-person adventure stories. Poetics 55: 3645.

Cohn N and Ehly S (2016) The vocabulary of manga: Visual morphology in dialects of Japanese visual language. Journal of Pragmatics 92: 19-29.

Cruz Petersen EM (2016) A mindful audience: Embodied spectatorship in Early Modern Madrid. In: Jaén I and Simon JJ (eds) Cognitive Approaches to Early Modern Spanish Literature, Oxford: Oxford University Press, pp111-127.

Cui Y (2016) Adjacency pairs and interactive consciousness in Virginia Woolf's novels. Style 50(2): 203-222.

Dancygier B and Vandelanotte L (2016) Discourse viewpoint as network. In:

Dancygier B, Wei-lun L, Verhagen A (eds) Viewpoint and the Fabric of Meaning:

Form and Use of Viewpoint Tools across Languages and Modalities. Berlin and

Boston: De Gruyter, pp. 13-40.

Dancygier B, Wei-lun L, Verhagen A (eds) (2016) Viewpoint and the Fabric of Meaning: Form and Use of Viewpoint Tools across Languages and Modalities. Berlin and Boston: De Gruyter.

Davies M (2013) Oppositions and Ideology in News Discourse. London and New 
York: Bloomsbury.

Edmundson M (2004) Why Read? New York: Bloomsbury.

Evans M (2016) From ornament to armament: the epistolary rhetoric of Lady Elizabeth Tudor. In: Auer A, González-Díaz V, Hodson J and Sotirova V (eds) Linguistics and Literary History: In honour of Sylvia Adamson. Amsterdam and Philadelphia: John Benjamins, pp. 49-69.

Fletcher A and Monterosso J (2016) The science of Free Indirect Discourse: An alternate cognitive effect. Narrative 24(1): 82-103.

Foxwell $\mathrm{J}$ (2016) Enacting hallucinatory experience in fiction: metalepsis, agency and the phenomenology of reading in Muriel Spark's The Comforters. Style 50(2): 139157.

Gavins J (2015) Text-Worlds. In: Sotirova V (ed) The Bloomsbury Companion to Stylistics. London and New York: Bloomsbury, pp. 444-457.

Gavins J and Lahey E (eds) (2016) World Building: Discourse in the Mind. London and New York: Bloomsbury

Genette G (1980) Narrative Discourse. Oxford: Blackwell.

Giovanelli M (2016) Text World Theory as Cognitive Grammatical: A pedagogical application in the secondary classroom. In: Gavins $\mathrm{J}$ and Lahey $\mathrm{E}$ (eds) World Building: Discourse in the Mind. London and New York: Bloomsbury, pp. 109-126.

Goodblatt C and Glicksohn J (eds) (2017) Bidirectionality and Metaphor. Special Issue of Poetics Today 38(1): 1-211.

Goodson IF and Gill SR (2011) The narrative turn in social research. Counterpoints, 386: $17-33$

González-Díaz V (2016) "Worth a moment's notice": Jane Austen and conversational parentheticals. In: Auer A, González-Díaz V, Hodson J and Sotirova V (eds) Linguistics and Literary History: In honour of Sylvia Adamson. Amsterdam and Philadelphia: John Benjamins, pp. 129-150.

Hescher A (2016) Reading Graphic Novels. Genre and Narration. Berlin and Boston: De Gruyter.

Hidalgo-Downing L, Martínez, MA, Kraljevic-Mujic, B (2016) Multimodal metaphor, narrativity and creativity in TV cosmetic ads. In: Romano M and Porto MD (eds) Exploring Discourse Strategies in Social and Cognitive Interaction. Amsterdam and Philadelphia: John Benjamins, pp.137-158.

Hühn P (2016) Facing Loss and Death. Narrative and Eventfulness in Lyric Poetry. Berlin and Boston: De Gruyter. 
Igl N and Zeman S (eds) (2016) Perspectives on Narrativity and Narrative Perspectivization. Amsterdam and Philadelphia: John Benjamins.

Janssen T and Braaksma M (2016) Effects of creative writing on adolescent students' literary response. In: Burke M, Fialho O and Zyngier S (eds) Scientific Approaches to Literature in Learning Environments. Amsterdam and Philadelphia: John Benjamins, pp. 193-212

Jaén I and Simon JJ (eds) (2016) Cognitive Approaches to Early Modern Spanish Literature. Oxford: Oxford University Press.

Jeffries L (2000) Don't Throw the Baby out with the Bathwater: In Defence of Theoretical Eclecticism in Stylistics. PALA Occasional Papers 12.

Jeffries L (2007) Textual Construction of the Female Body: A Critical Discourse Approach. Basingstoke: Palgrave Macmillan.

Jeffries L (2009) Critical Stylistics: The Power of Language. Perspectives on the English Language. Basingstoke: Palgrave Macmillan.

Jeffries, L (2015) Critical stylistics. In: Sotirova, V (ed) The Bloomsbury Companion to Stylistics. London: Bloomsbury, pp157-176.

Keen, S (2016) Pivoting towards empiricism: A response to Fletcher and Monterosso. Narrative 24(1): 104-111.

Klauk T, Köppe, T and Onea E (2016) More on narrative closure. Journal of Literary Semantics 45(1): 21-48.

Kress G and van Leeuwen T (2006) Reading Images: The Grammar of Visual Design $\left(2^{\text {nd }} \mathrm{ed}\right)$. London: Routledge.

Lakoff G and Johnson M (1980) Metaphors we Live by. Chicago: The University of Chicago Press.

Lee C (2016) A corpus-based approach to transitivity analysis at grammatical and conceptual levels: A case study of South Korean newspaper discourse. International Journal of Corpus Linguistics 21(4): 465-498.

Leech $\mathrm{G}$ and Short M (1981) Style in Fiction: A Linguistic Introduction to English Fictional Prose. London: Longman.

Leech G (2014) The Pragmatics of Politeness. Oxford: Oxford University Press.

Lively A (2016) Joint attention, semiotic mediation and literary narrative. Poetics Today 37(4): 517-538.

Llopis A, Villarejo B, Soler M and Alvarez P (2016) (Im)Politeness and interactions in Dialogic Literary Gatherings. Journal of Pragmatics 94: 1-11.

Louviot E (2016) Direct Speech in Beowulf and Other Old English Narrative Poems. 
Anglo-Saxon Studies 30. Cambridge: D.S. Brewer.

Louw WE (2000) Contextual Prosodic Theory: Bringing semantic prosodies to life. In: Heffer C and Sauntson $\mathrm{H}$ (eds) Words in Context. In Honour of John Sinclair. Birmingham: ELR. (http://www.revue-texto.net/docannexe/ le/124/louw_prosodie.pdf)

Louw B and Milojkovic M (2016) Corpus Stylistics as Contextual Prosodic Theory and Subtext. Amsterdam and Philadelphia: John Benjamins.

Lugea J (2016a) World Building in Spanish and English Spoken Narratives. London and New York: Bloomsbury.

Lugea J (2016b) A text-world account of temporal world-building strategies in English and Spanish. In: Romano M and Porto MD (eds) Exploring Discourse Strategies in Social and Cognitive Interaction. Amsterdam and Philadelphia: John Benjamins, pp.245-272.

Mahlberg M (2013) Corpus Stylistics and Dickens's Fiction. New York and London: Routledge.

Mahlberg M, Stockwell P, de Joode J, Smith C and Brook O'Donnell M (2016) CLiC Dickens: novel uses of concordances for the integration of corpus stylistics and cognitive poetics. Corpora 11(3): 433-463.

Mancing, H (2016) Embodied cognition and autopoiesis in Don Quixote. In: Jaén I and Simon JJ (eds) Cognitive Approaches to Early Modern Spanish Literature, Oxford: Oxford University Press, pp37-52.

Mclntyre D (2011) The place of stylistics in the English curriculum. In: Jeffries $L$ and Mclntyre D (eds) Teaching Stylistics. Basingstoke: Palgrave/English Subject Centre, pp.9-29.

McLoughlin N (2016) Into the futures of their makers: A cognitive poetic analysis of reversals, accelerations and shifts in time in the poems of Eaven Boland. In: Gavins $\mathrm{J}$ and Lahey E (eds) World Building: Discourse in the Mind. London and New York: Bloomsbury, pp.259-275.

Miall, DS (2006) Literary Reading: Empirical and Theoretical Studies. New York: Peter Lang.

Mildorf J and Kinzel T (eds) (2016) Audionarratology. Interfaces of Sound and Narrative. Berlin and Boston: De Gruyter.

Naweed, A (2016) The case of the crooked clock and the distracted driver. Narrative 24(2): 211-220.

Peplow D (2016) Talk about Books: A Study of Reading Groups. London and New York: Bloomsbury 
Pettersson B (2016) How Literary Worlds Are Shaped. A Comparative Poetics of Literary Imagination. Berlin and Boston: De Gruyter.

Pihlaja S (2014) Antagonism on YouTube: Metaphor in Online Discourse. London and New York: Bloomsbury.

Pilkington A (2000) Poetic Effects: A Relevance Theory Perspective. Amsterdam and Philadelphia: John Benjamins.

Reed, CA (2016) Embodiment and empathy in Early Modern drama: The case of Cervantes' El trato de Argel. In: Jaén I and Simon JJ (eds) Cognitive Approaches to Early Modern Spanish Literature, Oxford: Oxford University Press, pp183-201.

Richardson B (2015) Unnatural Narrative: Theory, History and Practice. Columbus, $\mathrm{OH}$ : Ohio State University Press.

Richardson B (ed) (2016a) Unnatural narrative. Special Issue of Style 50(4): 385-535.

Richardson B (2016b) Unnatural narrative theory. Special Issue of Style 50(4): 385405.

Ringrow H (2016) The Language of Cosmetics Advertising. Houndmills, Basingstoke: Palgrave Macmillan.

Romano M and Porto MD (2016) Introduction: Discourse, cognition and society. In: Romano M and Porto MD (eds) Exploring Discourse Strategies in Social and Cognitive Interaction. Amsterdam and Philadelphia: John Benjamins.

Ryan ML (1991) Possible Worlds, Artificial Intelligence and Narrative Theory. Bloomington, IA: Indiana University Press.

Schmitz R (2016) Theory of Mind in Early Modern Spanish manuals of courtly conduct. In: Jaén I and Simon JJ (eds) Cognitive Approaches to Early Modern Spanish Literature, Oxford: Oxford University Press, pp164-180.

Scott $J$ (2016) Worlds from words: theories of world-building as creative writing toolbox'. In: Gavins J and Lahey E (eds) World Building: Discourse in the Mind. London and New York: Bloomsbury, pp. 127-146.

Short M (2016) Stylistics and "He Wishes for the Cloths of Heaven" by W.B. Yeats. In: Auer A, González-Díaz V, Hodson J and Sotirova V (eds) Linguistics and Literary History: In honour of Sylvia Adamson. Amsterdam and Philadelphia: John Benjamins, pp. 195-211.

Simerka B (2016) The role of empathy in reading, interpreting and teaching Las Casas' Brevísima relación de la destrucción de las Indias. In: Jaén I and Simon JJ (eds) Cognitive Approaches to Early Modern Spanish Literature, Oxford: Oxford University Press, pp202-218. 
Simon, JJ (2016) Contextualizing cognitive approaches to Early Modern Spanish literature. In: Jaén I and Simon JJ (eds) Cognitive Approaches to Early Modern Spanish Literature, Oxford: Oxford University Press, pp13-33.

Sorlin S (2016) Language and Manipulation in House of Cards. A Pragma-Stylistic Perspective. Houndmills, Basingstoke: Palgrave Macmillan.

Sotirova V (ed) (2015) The Bloomsbury Companion to Stylistics. London and New York: Bloomsbury.

Statham S (2016) Redefining Trial by Media: Towards a Critical-forensic Linguistic Interface. Amsterdam and Philadelphia: John Benjamins.

Steinby L (2016) Time, space and subjectivity in Gérard Genette's Narrative Discourse. Poetics Today 37(4): 579-603.

Stockwell P (2000) The Poetics of Science Fiction. New York: Longman.

Stockwell P (2002) Cognitive Poetics: An Introduction. London and New York: Routledge.

Stockwell, P (2009) Texture: A cognitive aesthetics of reading. Edinburgh: Edinburgh University Press.

Stockwell P and Whiteley S (2014) (eds) The Cambridge Handbook of Stylistics. Cambridge: Cambridge University Press.

Tabbert U (2015) Crime and Corpus: The Linguistic Representation of Crime in the Press. Amsterdam and Philadelphia: John Benjamins.

Tabbert U (2016) Language and Crime: Constructing Offenders and Victims in Newspaper Reports. Houndmills, Basingstoke: Palgrave Macmillan.

Tognini-Bonelli T (2001) Corpus Linguistics at Work. Amsterdam: John Benjamins.

Toolan M (2016) Making Sense of Narrative Text. Situation, Repetition, and Picturing in the Reading of Short Stories. London and New York: Routledge.

Van der Bom I (2016) Speaker Enactors in Oral Narrative. In: Gavins J and Lahey E (eds) World Building: Discourse in the Mind. London and New York: Bloomsbury, pp.91-108.

van Hulle D and Kestemont M (2016) Periodizing Samuel Beckett's Works: A stylochronometric approach. Style 50(2): 172-202.

Vlieghe J, Muls J and Rutten K (2016) Everybody reads: Reader engagement with literature in social media environments. Poetics 54: 25-37.

Wang J, Xu Z, Mclntyre D, Lugea J and Ho Y (2016) Worldbuilder 1.0. Departments of Informatics and Linguistics \& Modern Languages, University of Huddersfield. 
Available at: http://www.viv-research.info/TWT/system/index.html (Last accessed 10 July 2017).

Werth P (1999) Text Worlds: Representing Conceptual Space in Discourse. Harlow: Longman.

Whiteley S (2016) Building resonant worlds: experiencing the text-worlds of The Unconsoled. In: Gavins J and Lahey E (eds) World Building: Discourse in the Mind. London and New York: Bloomsbury, pp. 165-181.

Zettelmann E (2017) 'Narrativity and world-building in the lyric', Plenary Lecture, $7^{\text {th }}$ Conference of the International Association of Literary Semantics. University of Huddersfield, 10-12 April.

Zyngier S (ed) (2016) Language, Discourse, Style: Selected works of John McH Sinclair. Amsterdam and Philadelphia: John Benjamins. 